\title{
Raising levels of school student engagement and retention in rural, regional and disadvantaged areas: Is it a lost cause?
}

\author{
Jeanne Maree Allen ${ }^{1}$, Suzie Wright ${ }^{2}$, Neil Cranston ${ }^{2}$, Jane Watson ${ }^{2}$, Kim \\ Beswick $^{3}$ and Ian Hay ${ }^{3}$ \\ ${ }^{1}$ School of Education and Professional Studies, Griffith University, Mt Gravatt, Australia \\ ${ }^{2}$ Faculty of Education, University of Tasmania, Hobart, Australia \\ ${ }^{3}$ Faculty of Education, University of Tasmania, Launceston, Australia
}

Corresponding author: Associate Professor Jeanne Maree Allen, School of Education and Professional Studies, Griffith University, 176 Messines Ridge Rd., Mt Gravatt, QLD, 4122, Australia. Tel: +61 737351031 Email: jeanne.allen@griffith.edu.au

Co-authors: Ms Suzie Wright, Faculty of Education, University of Tasmania, Private Bag 66, Hobart, TAS, 7001, Australia. Tel: +61 362262869 Email: Suzie.Wright@utas.edu.au

Professor Neil Cranston, Faculty of Education, University of Tasmania, Private Bag 66, Hobart, TAS, 7001, Australia. Tel: +61 362267404 Email: Neil.Cranston@utas.edu.au

Professor Emerita Jane Watson, Faculty of Education, University of Tasmania, Private Bag 66, Hobart, TAS, 7001, Australia. Tel: +61 362262570 Email: Jane.Watson@utas.edu.au

Professor Kim Beswick, Faculty of Education, University of Tasmania, Locked Bag 1308, Hobart, TAS, 7001, Australia. Tel: +61 363243167 Email: Kim.Beswick@utas.edu.au

Professor Emeritus Ian Hay, Faculty of Education, University of Tasmania, Locked Bag 1308, Hobart, TAS, 7001, Australia. Tel: +61 363243724 Email: Ian.Hay@utas.edu.au

Disclosure statement: This paper has not been previously published nor is it under consideration by another publication. This work was supported by the Australian Research Council under Grant number LP110200828; and Industry Partner, the Tasmanian Department of Education. The research was conducted through the University of Tasmania. 
This paper reports on the views of a set of key members of the educational community about student engagement and retention in rural, regional and disadvantaged areas of the Australian state of Tasmania. Forming part of a larger project undertaken with the Tasmanian Department of Education, this particular study provides important insights into the attributed reasons for the longstanding low levels of student retention in Tasmania, and the possible ways to militate against the widely censured problem of students leaving school too soon. The paper draws from principles of Bronfenbrenner's $(1979,1989)$ model of ecology to situate the 25 participants who formed the sample of the study in the exosystem of the environment of the young people whose educational attainment and retention in schools is the focus of this work. Findings generated through a thematic analysis of the data generated three major themes: Families and the socio-cultural environment; Teachers and teaching; and The school system. The study's findings serve an important role in prompting us to question when, and if, the dire situation of student dropout in the state and in similar contexts worldwide will begin to be reversed. Implications of the work include the need to develop and sustain a strong policy environment in which high quality education and schooling success are contextualised as key features to which members across the systems and sections of society, can contribute.

Keywords: behaviour; inclusive education; poverty \& education

\section{Introduction}

This paper draws from a large project funded by the Australian Research Council (ARC) and the Tasmanian Department of Education (DoE), which investigated issues associated with student engagement and retention ${ }^{1}$ in rural, regional and disadvantaged areas of the Australian state of Tasmania. Specifically, the paper presents and discusses the findings from interviews with a set of key members of the educational community (henceforth, 'key educators'), selected for their informed views about, on one hand, drivers of student engagement and retention in the state, and, on the other, factors that potentially lead to or intensify the likelihood of young people leaving school early. These matters are significant given that, for over a decade, Tasmania has had among the weakest levels of retention of students in formal education or training beyond Year 10 in Australia (ABS 2006, 2011, 2016; Cranston, Allen, Watson, Hay, and Beswick 2012; Cranston et al. 2016; Watson et al. 2013, Watson et al. 2016).

\footnotetext{
${ }^{1}$ As in previous publications (see, e.g., Cranston et al. [2016]), retention is broadly defined in this article as students staying in education beyond Year 10.
} 
Importantly, empirical and theoretical research into student retention throughout the world (including Tasmania) has generated important understandings in this area, as has the adoption of a range of policies and practices (Cranston et al. 2012, Cranston et al. 2016; Hay et al. 2016; Lamb, Walstab, Teese, Vickers, and Rumberger 2004; OECD 2013; Rumberger 2011; Te Riele, 2006; Watson et al. 2015; Watson et al. 2016). In light of this knowledge, as well as iterative attempts to improve retention levels in Tasmania by the Tasmanian Department of Education (DoE) and others, why is it that retention rates continue to languish? As Eslake (2015) noted recently, 'it is disturbing that little progress seems to be being made in reducing the shortfall in educational attainment between younger Tasmanians and their counterparts in other parts of Australia' (36). Add to this a comparison with counterparts internationally and the gravity of the situation comes to light. If we are to be more inclusive and ensure equity of educational opportunities for all students, we need to improve student engagement and retention in these types of areas of disadvantage.

Elsewhere, the authors of this paper have reported on a range of stakeholders' views about this complex problem, including parents (Hay et al. 2016) and members of the wider school community (Watson et al. 2015). In this paper, our purpose in giving voice to key educators is to provide insight into the views of one group of stakeholders who are strongly invested in schooling and who, in many cases, have the authority to drive educational change in the state. The importance of these stakeholders' perspectives should not be underestimated (Lamb et al. 2004).

The Tasmanian research context is outlined shortly. First, we provide a brief overview of the literature within the broader context for the study. Drawing from Bronfenbrenner (1979, 1989), we then situate the participant group within the exosystem of school life, describing the importance of key educators' attitudes and beliefs in relation to others in the ecological environment. Next, we outline the methods used in this component of the larger 
mixed methods study before presenting the findings and a discussion based on those findings in response to the central questions of this paper. We conclude with some of the ways in which the state is starting to move ahead on the issue of student retention.

\section{Literature: the importance of education}

It is now broadly accepted that continuing on in meaningful education past the compulsory years is not only highly desirable, but also essential for 'social cohesion and social prosperity, for economic competiveness, for employability, health and well-being of citizens' (Ramsay and Rowan 2013, 2). An extensive body of accumulated evidence testifies to the strong correlation between educational attainment and economic outcomes, both for economies as a whole as well as for individuals (Eslake 2015).

In other words, the consequences of student dropout are severe, not only for the individuals themselves but for the larger society and economy (Brown and Schafft 2011; Rumberger 2011). Research indicates that for every additional year of schooling added to the adult population, economic growth is augmented by between .25 and .75 of one percentage point per annum, which is to say between six and 19 per cent in the long term, after controlling for other factors shown to impact on long-term economic growth (Eslake 2015).

In the USA it has been shown that those who fail to complete the compulsory years of schooling never catch up with high school graduates on any measure. They are less likely to find work, and more likely to live in poverty, commit crimes, and suffer health problems. Even their life expectancy is shorter by seven years than for those who earn a diploma (Rumberger 2011). The social and economic repercussions are particularly grave in an era where knowledge production and application represent global priorities:

Graduating from upper secondary education has become increasingly important in all countries, as the skills needed in the labour market are becoming more knowledge-based 
and as workers are progressively required to adapt to the uncertainties of a rapidly changing economy. (OECD 2013, 42)

In this context, where school attainment is a strong predictor of the wealth that will be generated in the long run (OECD 2015), students in rural and disadvantaged areas are often faced with more limited educational choices and thus more uneven life opportunities than those residing in urban environments (Baeck and Paulsgaard 2012).

The reasons why students disengage and drop out of school are complex and multifaceted, with no easy answers or quick fixes. In Canada, for example, Wallin (2007) points to the myriad ways in which rural settings are beset with educational problems that hinder student inclusion and academic achievement, including: isolation from specialised services, teacher shortages in key subject areas and high staff turnover, limited accessibility to high quality staff professional learning and tertiary services, and educational funding formulae that fail to meet the challenges of service delivery in rural and remote areas. These and similar issues have been encountered and reported worldwide (e.g., Baeck and Paulsgaard [2012]; Brown and Schafft [2011]).

In our larger study (e.g., Cranston et al. [2016]), we have approached student dropout as a 'wicked problem' (Rittel and Webber 1973), that is, as a highly complex educational, social and cultural problem, involving issues that require 'thinking that is capable of grasping the big picture, including the full range of causal factors underlying them’ (APSC 2007, iii). It is clear from what has been reported internationally over an extended period of time (e.g., Rumberger 2011) that school dropout is 'highly resistant to solution' (APSC 2007, iii) and that there is no 'one size fits all' approach to the required changes. Rather, there are a range of policies, initiatives and interventions internationally that have been, or show promise of being, effective in enhancing student engagement and retention (see, e.g., Brown and Schafft [2011]; Schafft and Jackson [2010]; Theobald [1997]; Wallin [2007]). 


\section{Context}

The Australian state of Tasmania has the most rurally dispersed population of the six Australian states ${ }^{2}$ and, with an area of a $68,401 \mathrm{~km}^{2}$ and a population of just over 500,000 , it is also the smallest state on both measures. As we have reported previously (Cranston et al. 2016), it is also the most socio-economically disadvantaged of all the states, as measured by a number of socio-economic indices—including disposable household income, adult and youth unemployment rates. Over one-third of the population receives government public financial assistance (ABS 2007). Although 86\% of the jobs in Australia require a post-Year 12 qualification, in 2007 only 47\% of Tasmania’s workforce had that level of qualification.

A review of student data over the last 10 to 15 years reveals worrying trends for Tasmania (ABS 2006, 2011, 2016). Although the apparent retention rates for students moving from early secondary schooling (Year 7/8) to Year 10 are comparable to all other states and the Australian Capital Territory (ACT) (see Figure 1), there is a significant drop in the retention of students moving into the senior secondary years (Figure 2). This is true for students across Australia, however the rate of loss in Tasmania is greater than that of all other states and territories. For example, in 2015 the apparent retention rate for students moving from Year 7/8 to Year 10 in Tasmania was 100\%, yet the rate for Year 10 to Year 12 was only $72 \%$, a drop of $28 \%$. For the same year, the drop in retention rates for students in other parts of Australia ranged from 23\% for New South Wales to only 5\% in the ACT. Figure 2 also illustrates another disturbing trend for Tasmania, that is, the apparent retention rate of students to Year 12 has seen almost no improvement over the past 15 years. In fact, the retention rate in 2015 was almost the same as it was in 2000 (72.1\% and 71.6\% respectively).

\footnotetext{
${ }^{2}$ Australia comprises six states and two territories, and a population of approximately 24 million.
} 
While all other states and the ACT have made improvements in their apparent retention rates since 2000, the rate in Tasmania remains stagnant.

[Insert Figure 1 here]

[Insert Figure 2 here]

Levels of student attainment are equally concerning, when compared to those of students’ contemporaries elsewhere. Recently released preliminary data from the 2016 National Assessment Program - Literacy and Numeracy (NAPLAN) tests indicate that Tasmanian students languish in sixth or seventh position for literacy and numeracy across the year levels (ABS 2007), with the Northern Territory trailing in eighth position (ACARA 2016). Of even more concern is that trends indicate that since the introduction of the nationwide tests in 2008, Tasmanian students have fallen behind those in other states across most year levels and subject domains (ACARA 2016).

Commonly purported to be an issue of concern in Tasmania is the structure of the state school system. Unlike in the rest of the nation (the ACT notwithstanding), Years 11 and 12 (in government schools) have historically been separated from high school (Years 7 to 10) into senior secondary colleges, resulting in eight colleges in the four largest population centres. This model, which dates back to the 1960s, was developed because of the small numbers of students in selective high schools, especially in rural areas, and a shortage of qualified teachers for matriculation subjects. Advantages of the model include the consolidation of teacher expertise and the provision of a range of curriculum offerings, but these are offset by the adverse impact on rural and remote students of travel time and accommodation, as well as separation from family (e.g., Stewart and Abbott-Chapman [2011]). Further, the demarcation between schools (Year 10 to college) has come to represent 
for some students and their families, especially in rural areas, the completion of schooling at the end of Year 10.

\section{An ecological approach}

In this paper we draw on Bronfenbrenner’s $(1979,1989)$ model of ecology to theorise that key educators, such as those who formed the sample for this study, play an important role in shaping the decision making of the nation's youth in terms of how these young people interact with, and are influenced by their schooling environment. This has been demonstrated not only through the theoretical work of Bronfenbrenner $(1979,1989)$ and others, but also through empirical research (e.g., Berns [2012]; Smith [2014]). Interactions and influences of these kinds are seen to be predictive of levels of student engagement and retention in school.

Bronfenbrenner (1979) conceives of the ecological environment in which the development of human beings_-in our case, students—occurs as an arrangement of concentric structures, comprising four systems: the micro-, meso-, exo-, and macrosystems (see Figure 3).

[Insert Figure 3 here]

The microsystem encapsulates the immediate interpersonal relations, roles and activities experienced by the student in settings, such as the family and school, while the mesosystem comprises the interrelations and patterns of activities among two or more settings, for example, the relations between home and school. Of particular relevance to this study is the third nested system, the exosystem, which encompasses the meso- and microsystem and

refers to one or more settings that do not involve the developing person as an active participant, but in which events occur that affect, or are affected by what 
happens in the setting containing the developing person. (Bronfenbrenner 1979, 25).

Finally, the macrosystem comprises the overarching commonalities between the other, lowerorder systems, including cultural and social norms, belief systems and ideologies (Bronfenbrenner 1979).

Although our interest lies with key educators situated in the exosystem, it must be noted that it is not the intention of this paper to explore the interplay between the psychological characteristics of students and the exosystem of their environment (in which our participants are located). Rather, we theorise that 'higher levels of the environment can act to directly influence ... values and beliefs' of those in the lower levels of the environment (Wachs 1992, 42) and that, therefore, the individuals, groups, patterns of behaviour and activity within the exosystem can influence the outcomes of an individual at the heart of the microsystem. Within this frame, we examine one particular exosystemic group's beliefs and attitudes about student engagement and retention. The significance of this group lies in the fact that decisions made by its members - key educators - play an important role in shaping the development of young people in their interplay with the schooling environment, including their choices about remaining at school. Many of those interviewed are also in a position to influence policy, specifically in the sorts of choices made, and actions taken to enhance student retention.

\section{Methods}

The data collection used a snowball technique, starting with key members of the DoE and continuing with other members of the educational community nominated by interviewed participants as having views on and/or experiences related to student engagement and retention that were potentially relevant to the aims of the project. The project team was also provided with the names of potential participants by an array of people, such as school 
principals and teachers. Given the nature of the snowball technique, the sample increased as we progressed with the interviews, and the interview process continued until we reached saturation of the data (Cohen, Manion, and Morrison 2011). In total, 42 members of the educational community were invited to participate, of whom 25 were interviewed (60\% response rate). Nineteen interviews with key educators were conducted: sixteen with individuals, two each with two participants, and one interview with a group of five. Fifteen of the interviewees were representatives of the DoE, including four General Managers, each with responsibility for one of the state's educational jurisdictions ${ }^{3}$; four held positions within the former Tasmanian Polytechnic ${ }^{4}$; four were school principals with additional roles in the DoE administration; and two represented the university sector.

The interview process was semi-structured (Patton 2015), with the interview protocol (see Watson et al. [2015]) supplied to participants beforehand. Interviews, which took between 30 minutes and 1.75 hours, were audio-taped with participant consent and subsequently transcribed for detailed analysis. Using a member checking approach (Cohen et al. 2011), participants were provided with a copy of the transcript and given the opportunity to amend it.

The data were analysed through a thematic approach (Patton 2015), which involved two researchers each separately reading the 19 interview transcripts to identify and record patterns that responded in some way to the research questions. Subsequently, the two sets of recorded patterns were compared and contrasted, with inconsistencies resolved through further interrogation of the data, both by the two researchers and an additional member of the

\footnotetext{
${ }^{3}$ At the time of interviewing, the state's school system was divided into three geographical regions North, North-West, and South - and overseen by four General Managers (two for the Southern region). More recently, the DoE consolidated these jurisdictions into two services: Learning Services (Northern Region), and Learning Services (Southern Region) (http://www.education.tas.gov.au/).

4 The Tasmanian Polytechnic, now TasTAFE, is a Tasmanian Government owned vocational education and training provider (http://www.tastafe.tas.edu.au).
} 
research team. This iterative process, which included regular discussion meetings of the full research team, resulted in the generation of a number of themes, which were then grouped into three overarching themes. Together these themes, presented in the next section, serve as the study’s findings. Salient quotations were identified during the data analysis process and are included in the discussion below. Each quotation includes the participant ID code consisting of the institution and interview number, e.g., University Rep_01, and the transcript page number.

\section{Findings and discussion}

In this section, we address two inter-related research questions (RQs) underpinning this paper, namely:

RQ1: In the view of key educators, what are the major reasons for the relatively low levels of student engagement and retention in Tasmania?

RQ2: In the view of key educators, what can be done to raise student engagement and retention levels in the state?

In doing so, we seek to provide insight into issues related to student inclusion, engagement and retention, which are of interest and significance to those dealing with these types of issues in similar contexts elsewhere. Building on our and others' research, and in line with the ecological approach we have taken in this work, we also seek to demonstrate ways in which the educational development and learning outcomes of young people are impacted by myriad influences across the systems and sections of society—by workers, neighbours, friends, members of organisations, committees, boards, and the informal networks that control our social institutions (Bronfenbrenner, 1979). 
Analysis and interpretation of the data generated three overarching themes: (1)

Families and the socio-cultural environment, (2) Teachers and teaching, and (3) The school system (see Table 1 ).

[Insert Table 1 here]

\section{Families and their socio-cultural environment}

A salient finding of the study was the number of seemingly inexorable socio-cultural and inter-generational factors that were seen to impact negatively on levels of student retention. Many attributed what could be perceived as the endemicity of student disengagement and dropout in some areas to family and socio-cultural factors that have been shown to be very hard to mitigate (Rumberger 2011). In particular, participants noted how attitudes towards education were hard to shift in families and communities steeped in poverty, long-term unemployment, and family dysfunction. As one of the principals explained it:

We definitely do have a generational culture ... around our kids. It’s just generational offending. Dad's been to jail, mum's been to jail, pop’s been to jail. There is almost a rite of passage. (Principal_03, p. 22)

The issue of moving away from home was also identified as a source of tension for young people and their families from a range of perspectives-practical, financial, emotional_ and was seen to diminish the desire and resolve of some to remain in education:

...for parents, even if they value education they have got those barriers around finance, around distance. (Polytech Rep_03, p. 5)

These are findings that confirm an extensive body of literature demonstrating the deep-seated impact of socio-economic circumstances on educational attainment and student retention. Rumberger (2011), for example, notes that 'Family background is widely recognized as the 
single most important contributor to success in school. Socioeconomic status ... is a powerful predictor of school achievement and dropout behaviour' (9). Students from low socioeconomic status (SES) communities may have constrained opportunities to connect with further and higher education due to an array of resource limitations (Lamb, Jackson, Walstab, and Huo 2015) and may also have few role models or contacts among their family and peer group with experience of higher educational attainment (Lamb et al. 2004). Interestingly, Tasmania’s low levels of student attainment and retention cannot be attributed to low SES backgrounds per se. As Eslake (2015) points out, Tasmanian students have lower levels of retention than their counterparts in other states and territories (with the exception of the Northern Territory), regardless of their SES backgrounds.

What is notable here is that the key educators whose voices are captured in this paper are arguably those in the very position to make a difference and to drive change; and yet, judging by their comments and reported perceptions about this particular issue, they seem powerless to do anything about it. Does this suggest that we will see little difference in the future than in the past? That Tasmania will continue to languish at the bottom of educational achievement scales? Although we concede that this type of commentary is hardly helpful in developing a positive orientation towards the future, it certainly resonates with the public perception in some quarters that the state is in an unmanageable position. In a deliberately provocative piece, West (2013) had the following to say:

Tasmania ranks at the bottom among Australian states on virtually every dimension of economic, social, and cultural performance: highest unemployment, lowest incomes, languishing investment, lowest home prices, least educated, lowest literacy, most chronic disease, poorest longevity, most likely to smoke, greatest obesity, highest teenage pregnancy, highest petty crime, worst domestic violence. It seems not to matter which measure is chosen, Tasmania will likely finish last. (n. p.) 
He goes on to argue that, despite ongoing discussion and debate about these problems and 'self-reproducing pattern[s] of failure' (n. p.), there is scant attention paid to the 'uncomfortable truths at the source of underperformance' (n. p.). In the current study, however, another notable point is that participants $d o$ confront the core issues or 'uncomfortable truths' associated with low levels of educational attainment and student retention in areas of disadvantage. The problem lies not in confronting the issues but in finding ways to resolve them.

\section{Teachers and teaching}

On the topic of student engagement, one participant made the discerning comment that ...the prevailing and consistent findings seem to suggest that this notion of encouraging interest, curiosity, enthusiasm, and also setting high expectations of learning - this is where the teacher comes in, having high expectations of students and then helping to provide them with the skills to achieve those expectations. (University Rep_01, p. 7)

In this statement, she typified the attitudes reported by the key educators in this study about the role of teachers and school leaders in enhancing student attainment. There were mixed views about how well they did this, and about the quality of teachers and teaching in the state. Teacher pedagogy and performance in secondary schools in particular drew some criticism. For example, when asked to elaborate on claims she had made about the lack of academic rigour and low level quality teaching in Tasmanian schools, one DoE representative responded that:

I think where we have the real issue in Tasmania is in high schools. ... A lot of primary schools are doing really, really good work. ... Colleges work well for a lot of kids although not for all.... The real worry for me is high schools and what happens in high schools. (DoE Rep_03, pp. 5-6) 
Of particular concern was the ascribed inadequate level of engagement in ongoing and professional learning by many teachers, and the ramifications for student engagement and retention:

[High school teachers] are still not getting the training around literacy and numeracy strategies or even behaviour management really. I don’t know why that's not the case but it is the case so that means that we've got to work differently. (Principal_04, p. 10)

Participants expressed misgivings about the stalled mobility of the workforce, with many teachers-particularly those in colleges_-deemed unlikely to ever move schools or regions, and also about the aging teacher population and the stagnation of teaching practices:

I think the more teachers that can be highly skilled, of top quality and inspirational, the better it's going to be for kids. So how you actually turn around a relatively aging workforce to become enthusiastic and high quality and inspirational is a big challenge. (DoE Rep_01, p. 15)

There was some optimism expressed about positive ways forward, particularly by the General Managers, one of whom commented that:

We've had a very strong focus on working with [targeted] schools around school improvement, particularly literacy and numeracy. ... So if we build teachers' capacity there, we're pretty confident that that will have a longer term benefit. (DoE Rep_11-15, p. 5)

For many others, their projections for the future were mediated by countervailing factors and systemic barriers deemed to have stymied progress in the past. Participants referred to obstacles such as the recalcitrance of the Tasmanian branch of the Australian Education Union in the face of reform, including the introduction of the Australian Curriculum (ACARA 2016), with one DoE representative noting that: 
Every time we've seen the introduction of things like the national curriculum we've seen the Tasmania branch of the AEU particularly being very resistant to that, and not resistant necessarily on the grounds of learning or futures for students. They've been resistant on grounds of, perhaps, insecurity and the delivery of national curriculum, whether our teachers are skilled enough, those sorts of things; the holidays, that sort of stuff. (DoE Rep_10, pp. 5-6)

Also raised as areas of concern were the Tasmanian school culture, characterised by 'kids jumping through hoops around a target and $\mathrm{TCE}^{5}$ points and subject results as opposed to having a real zest [to] get up out of bed' (DoE Rep_08, p. 10); and the intensification of teachers’ work impacting negatively on their capacity to teach and enthuse students effectively.

These types of issues and concerns are of course not unique to Tasmania. Throughout the nation and in many countries internationally, public confidence in teacher quality has fallen and there is much attention being paid to ways to improve teacher quality and the quality of teaching and learning (OECD 2014), with one particular focus being teacher education and professional development (Johnston and Hayes 2007; Teacher Education Ministerial Advisory Group 2014). In the case of Tasmania, if teaching improvement is to occur, it will require not only robust and sustained policy and strategic planning and action but also that schools adopt a state of readiness for change-shown to be essential to school growth (see, e.g., Lynch, Madden, and Doe [2015]) — which underscores the importance of a shift in beliefs and attitudes among those in some quarters who remain resistant to change.

\section{The school system}

\footnotetext{
${ }^{5}$ Tasmanian Certificate of Education
} 
The senior secondary college model featured as another area of concern among the key educators interviewed in the study. With regards to the model itself-the separation of government schools into high schools (Years 7 to 10) and colleges (Years 11 and 12)—views were mixed, with, on the one hand, some participants identifying the advantages that the model accommodated students; for example:

I see the Grade 11 and 12 system that we have in this state as a great asset once kids get there. I think ... [it's] simplistic stuff ... [that] we could improve retention by just putting Grade 11 and 12 back in high schools. (Principal_04, p. 18)

On the other hand, there were criticisms leveled at the lack of congruence, particularly in terms of school and teacher culture, between high schools and colleges:

[There's a] massive big change in culture [between high schools and colleges]. So, yeah, I think that is obviously one of the barriers to maintaining retention. (DoE Rep_07, p. 3)

Views were much more uniform around the challenges posed by the school model for young people in rural areas, particularly with regards to transport and accommodation associated with travelling to school and/or leaving home. These comments are indicative:

Rural students are most definitely at a disadvantage. Travel and access to higher education and diverse curricular opportunities can be problematic. (Principal_03, p. 11)

Apart from [name] Hostel, the other accommodation doesn't have onsite supervision by an adult. My experience of that is that it’s not good. (DoE Rep_03, p. 28)

College timetables were also noted as an impediment for some, with students sometimes required to travel long distances for only one or two timetabled lessons on a particular day. Several participants suggested that more flexibility in the timetabling, for example, running a full program over four (rather than five) days, might curb the high levels of absenteeism in some colleges. Change in this direction was already underway according to 
the General Managers who reported that recent timetable restructuring had resulted in 'some flexibility to make sure we keep our kids in’ (DoE Rep_11-15, p. 16).

As noted earlier, these types of challenges to students' ongoing inclusion and engagement in education have been frequently reported before, both within the state (e.g., Stewart and Abbott-Chapman [2011]; Watson et al. [2015]) and in similar areas of rurality nationally (e.g., Lamb et al. [2015]) and internationally (e.g., Baeck and Paulsgaard [2012]). Many participants were hopeful that the expansion of the NBN and online learning might militate against some of these challenges and provide new educational opportunities for those choosing to stay in their rural communities. Others were more tentative, questioning whether the lack of social connection with peers might add to the vulnerability of students already in areas of educational risk.

Strong support was expressed for a number of retention initiatives and programs, developed and facilitated under the auspices of community, government and not-for-profit (NFP) groups, including: 'Dream Big,' a Burnie ${ }^{6}$ City Council community engagement and career guidance program for Year 5 students; Aboriginal Community Links, an information and referral service led by a Tasmanian NFP organisation, Colony 47; and Project Hahn, a Department of Health and Human Services initiative providing outdoor recreation activities to encourage personal and social development. The availability of alternative pathways to the traditional Preparatory to Year 12 was also strongly supported.

One of the issues raised was that of the sustainability of these and other educational initiatives, with participants reporting that programs were often discontinued, and 'quick fix band aid options’ (DoE Rep_05, p. 17) introduced. They expressed frustration that, despite well-meaning intentions on the part of the instigators, many attempts at effecting change were stymied by a lack of connectedness and fair distribution of resources across the state.

\footnotetext{
${ }^{6}$ A city of approximately 20,000 on Tasmania’s north-west coast
} 
Regrettably, this type of participant response to the problem is neither unexpected nor context-specific (see, e.g., Rumberger's [2011] research in the USA). Again underscored here is that the problem is complex, requiring a response on a number of fronts.

\section{Conclusion}

In this paper, we have given voice to key members of the educational community in relation to student engagement and retention in areas of rurality, regionality and disadvantage. Drawing from principles of Bronfenbrenner's $(1979,1989)$ model of ecology, we contend that these key educators, situated in the exosystem of school students' lives, have a strong bearing on students' choices about, and involvement in schooling, both directly through their influence on policy and practice, and more indirectly through their enacted beliefs about educational attainment and student retention in the state of Tasmania.

As in the larger project from which this study is drawn, the findings are sobering, largely because the same issues, which mirror some of those found in similar environments nationally and internationally, have been identified before—and created levels of considerable disquiet before. Notably, the in-depth case studies of our larger research project produced comparable themes (Cranston et al. 2016), which denotes the similarity of beliefs and views held by a range of stakeholders about the 'wicked problem' of overcoming the challenges of keeping young people in education (Cranston et al. 2016). This might lead us to question whether retention levels will continue to stagnate into the future and, more fundamentally, whether school student engagement and retention in the state is a lost cause.

Clearly, these questions, which we raise as a provocation, are incompatible with the aspirations we must uphold for the education of our young people in a knowledge society, where equity of access to, and inclusion in educational opportunities is essential. Further it must be stated in conclusion that the participants interviewed, while acknowledging what 
could reasonably be referred to as the enormity of the problem, all held promise for better educational futures for the young people of the state. Many also expressed unwavering commitment to play a role in finding solutions to the myriad problems that prevail in keeping students engaged in schooling.

In terms of ways forward, it is particularly encouraging that, quite recently, there has been a mobilisation of interests and forces, with new possibilities arising. For example, the DoE has commissioned a number of policy reviews in its attempt to address student retention and curb student dropout in Tasmania. A \$250,000 review of Years 9-12 is planned for 201617 with increased levels of inclusion, retention and attainment key priorities (DoE 2016). The most notable change in policy in recent years, however, is the extension of Years 11 and 12 progressively in urban and regional high schools across Tasmania. This initiative is specifically designed to improve educational outcomes for rural, regional and disadvantaged students by removing some of the barriers associated with the current senior secondary/college system of education, such as travel, moving away from home, and loss of community support ${ }^{7}$.

Proposed changes to the Tasmanian Education Act, current at the time of writing, will increase the number of compulsory years of schooling to parallel those in much of the rest of Australia and comparable nations. Under the new Act, all young people from the age of three and a half will be provided a place in public schooling until they enter full time employment, complete Year 12 or a Certificate Level III, or reach the age of 18. Beyond the policy level, the DoE is working closely with the University of Tasmania in an effort to increase participation in higher education. Numerous programs exist under the umbrella of the

\footnotetext{
${ }^{7}$ No changes to the current delivery of senior secondary schooling at the existing urban colleges have been announced; however it is expected that secondary schools undertaking the extension to Years 11 and 12 will partner with their nearest college "to ensure their students can study close to home while still having access to a wide variety of course options” (DoE 2015, p. 2).
} 
Schools Engagement Plan (University of Tasmania 2014), ranging from pathway planning and career advice, enrichment programs for high achieving students, access to university courses for Year 11 and 12 students, outreach programs and workshops, and targeted bursaries and scholarships.

Perhaps the real challenge, however, to making a real difference in young people continuing meaningfully in school is not only to ask the hard questions, but to accept that there are some challenging, long term responses that are required across the board. For too long it seems that we have known what the issues are and, indeed, what some of the solutions are. But effecting a change for many young people has essentially been a failure. The findings from this research re-enforce the fact that things have to change as we go forward. There are major agendas identified here to support that future. In particular, this research supports and emphasises the need for a whole-of-state approach to creating better educational futures for its young people. The three themes generated through our study-families and the socio-cultural environment; teachers and teaching; and the school system — underscore the importance of developing and sustaining a strong policy environment in which high quality education and schooling success are contextualised as key features to which all of us, across the systems and sections of society, can contribute.

\section{References}


ABS (Australian Bureau of Statistics). 2006. Schools Australia 2005. Cat No. 4221.0. Canberra, ACT: Author.

ABS (Australian Bureau of Statistics). 2007. Australian Demographic Statistics, Cat. No. 3101.0. Canberra, ACT: Author.

ABS (Australian Bureau of Statistics). 2011. Schools Australia 2010. Cat No. 4221.0. Canberra, ACT: Author.

ABS (Australian Bureau of Statistics). 2016. Schools Australia 2015. Cat No. 4221.0. Canberra, ACT: Author.

ACARA (Australian Curriculum, Assessment and Reporting Authority). 2016. NAPLAN Preliminary Results 2016. Canberra, ACT: Australian Government. http://reports.acara.edu.au/NAP/NaplanResults

APSC (Australian Public Service Commission). 2007. Tackling Wicked Problems: A public policy perspective. Canberra, ACT: Author.

Baeck, U.-D. K., and G. Paulsgaard. 2012. Rural futures? Finding one’s place within changing labour markets. Stamsund, Norway: Orkana Akademisk.

Berns, R. 2012. Child, family, school, community: Socialization and support. 9th ed. Belmont, CA: Wadsworth.

Bronfenbrenner, U. 1979. The ecology of human development: Experiments by nature and design. Cambridge, Mass: Harvard University Press.

Bronfenbrenner, U. 1989. “Ecological systems theory.” In Six theories of development: Revised formulations and current issues, edited by R. Vasta, 187-249. Greenwich, CT: JAI Press.

Brown, D. L., and K. A. Schafft. 2011. Rural people and communities in the 21st Century: Resilience and transformation. Polity: Malden, MA.

Cohen, L., L. Manion, and K. Morrison. 2011. Research methods in education. 7th ed. Abingdon, UK: Routledge. 
Cranston, N., J. M. Allen, J. Watson, I. Hay, and K. Beswick. 2012. “Findings of a pilot study into student retention beyond year 10.” In Proceedings of the Australian Association for Research in Education annual conference, edited by J. Wright. Sydney, NSW: AARE. http://www.aare.edu.au/publications-database.php/6667/findings-from-apilot-study-into-student-retention-beyond-year-10

Cranston, N., J. Watson, J. M. Allen, S. Wright, I. Hay, K. Beswick, C. Smith, W. Roberts, and B. Kameniar. 2016. "Overcoming the challenges of keeping young people in education: A wicked problem with implications for leadership, policy and practice.” Leading \& Managing 22 (1): 1-18.

DoE (Department of Education). 2016. Tasmanian Budget 2016-17. Budget Fact Sheet: Years 9-12 Review. Hobart, Tas: Tasmanian Government. https://www.education.tas.gov.au/documentcentre/Documents/047_16_Factsheet_912_Review_Web.pdf

DoE (Department of Education). 2015. Extending Years 11 and 12 Programme. Hobart, Tas: Tasmanian Government. https://www.dropbox.com/s/fig4afttaqpsoan/ExtendingYears-11-and-12-Programme-Fact-Sheet.pdf?dl=0

Eslake, S. 2015. Tasmania report. Hobart, Tas: Tasmanian Chamber of Commerce and Industry.

Hay, I., S. Wright, J. Watson, J. M. Allen, K. Beswick, and N. Cranston. 2016. "Parent-child connectedness for schooling and students’ performance and aspirations: An exploratory investigation.” International Journal of Educational Research 77: 50-61. doi.org/10.1016/j.ijer.2016.02.004.

Johnston, K. and D. Hayes. 2007. “Supporting student success at school through teacher professional learning: The pedagogy of disrupting the default modes of schooling.” International Journal of Inclusive Education 11 (3): 371-381. http://dx.doi.org/10.1080/13603110701240666.

Lamb, S., J. Jackson, A. Walstab, and S. Huo. 2015. Educational opportunity in Australia 2015: Who succeeds and who misses out? Melbourne, Vic: Mitchell Institute. 
http://www.mitchellinstitute.org.au/reports/educational-opportunity-in-australia-2015who-succeeds-and-who-misses-out

Lamb, S., A. Walstab, R. Teese, M. Vickers, and R. W. Rumberger. 2004. Staying on at school: Improving student retention in Australia. Brisbane, Qld: Dept of Education and the Arts.

Lynch, D., J. Madden, and T. Doe. 2015. Creating the Outstanding School. London: Oxford Global Press.

OECD (Organisation for Economic Co-operation and Development). 2013. Education at a Glance: OECD indicators. Paris: Author.

OECD (Organisation for Economic Co-operation and Development). 2014. Talis 2013 results: An international perspective on teaching and learning. Paris: Author.

OECD (Organisation for Economic Co-operation and Development). 2015. Universal basic skills: What countries gain to stand. Paris: Author.

Patton, M. Q. 2015. Qualitative research and evaluation methods. 4th ed. Thousand Oaks, CA: Sage.

Ramsay, E., and M. Rowan. 2013. Learning to Change Tasmania. Hobart, Tas: University of Tasmania. http://www.tasmanianleaders.org.au/wpcontent/uploads/2014/04/Learning-to-Change-Tasmania.pdf

Rittel, H. W. J., and M. M. Webber. 1973. "Dilemmas in a general theory of planning.” Policy Sciences 4 (2): 155-169. doi:10.1007/BF01405730

Rumberger, R. W. 2011. Dropping Out: Why students drop out of high school and what can be done about it. Cambridge, MA: Harvard University Press.

Schafft, K. A., and A. Y. Jackson, ed. 2010. Rural education for the twenty-first century: Identity, place, and community in a globalizing world. University Park, PA: Pennsylvania State University Press.

Smith, G. A., ed. 2014. Public schools that work: Creating community. New York: Routledge. 
Stewart, A., and J. Abbott-Chapman. 2011. “Remote island students’ post-compulsory retention: Student emplacement and displacement as factors influencing educational participation and persistence.” Journal of Research in Rural Education 6 (6): 1-16. http://jrre.psu.edu/articles/26-6.pdf

Teacher Education Ministerial Advisory Group. 2014. Action Now: Classroom Ready Teachers Report. Canberra, ACT: Department of Education. https://docs.education.gov.au/system/files/doc/other/action_now_classroom_ready_te achers_accessible.pdf

Te Riele, K. 2006. “Schooling practices for marginalized students — practice-with-hope.” International Journal of Inclusive Education 10 (1): 59-74. http://dx.doi.org/10.1080/13603110500221750

Theobald, P. 1997. Teaching the Commons: Place, pride, and the renewal of community. Boulder, CO: Westview Press.

University of Tasmania. 2014. Schools Engagement Plan (2014-2016). Report against Plan for 2014. Hobart, Tas: Author. http://www.utas.edu.au/_data/assets/pdf_file/0005/738221/Schools-EngagementPlan-2014-2016-Report-Against-Plan-2014.pdf

Wachs, T. D. 1992. The nature of nurture. Vol. 3 of Individual Differences and Development Series. Newbury Park, CA: Sage.

Wallin, D. C. 2007. "Policy window or hazy dream? Policy and practice innovations for creating effective learning environments in rural schools.” Canadian Journal of Educational Administration and Policy, no. 63. http://www.umanitoba.ca/publications/cjeap/pdf_files/wallin.pdf

Watson, J., J. M. Allen, K. Beswick, N. Cranston, I. Hay, S. Wright, and L. Kidd. 2013. “Issues related to students’ decisions to remain in school beyond Year 10.” Youth Studies Australia 32 (2): 21-29. http://apo.org.au/node/47777

Watson, J., S. Wright, K. Beswick, J. M. Allen, I. Hay, and N. Cranston. 2015. “Listening to the community on student retention.” In Proceedings of the Australian Association for Research in Education annual conference, Fremantle, WA. 
http://www.aare.edu.au/publications-database.php/9770/listening-to-the-communityon-student-retention

Watson, J., S. Wright, K. Beswick, I. Hay, J. M. Allen, and N. Cranston. 2016. Rural and regional students' perceptions of schooling and factors that influence their aspirations. Australian and International Journal of Rural Education 26 (2): 4-18.

West, J. 2013. “What's wrong with Tasmania, Australia's freeloading state?” Crikey, Jan. 30. https://www.crikey.com.au/2013/01/30/whats-wrong-with-tasmania-australiasfreeloading-state 
Table 1. Themes generated through data analysis.

\begin{tabular}{|c|c|c|}
\hline Overarching theme & Sub themes & Related issues \\
\hline \multirow[t]{2}{*}{$\begin{array}{l}\text { Families and the socio- } \\
\text { cultural environment }\end{array}$} & Generational factors & $\begin{array}{l}\text { Unemployment; family } \\
\text { history and early school } \\
\text { leaving }\end{array}$ \\
\hline & Reluctance to change & $\begin{array}{l}\text { Involvement in family life; } \\
\text { moving away from home }\end{array}$ \\
\hline \multirow[t]{2}{*}{ Teachers and teaching } & Roles of teachers & $\begin{array}{l}\text { Enhancing student } \\
\text { engagement to leverage } \\
\text { retention; teacher mobility }\end{array}$ \\
\hline & Teacher and teaching quality & $\begin{array}{l}\text { Pedagogy and professional } \\
\text { learning; systemic barriers } \\
\text { and influence on students }\end{array}$ \\
\hline \multirow[t]{2}{*}{ The school system } & The college model & $\begin{array}{l}\text { Separation of senior } \\
\text { secondary schools; } \\
\text { timetabling, transport, } \\
\text { accommodation }\end{array}$ \\
\hline & Scope for change & $\begin{array}{l}\text { National Broadband } \\
\text { Network (NBN); programs } \\
\text { and initiatives }\end{array}$ \\
\hline
\end{tabular}


Figure 1. Apparent retention rates (2006-2015) for Year 7/8 to Year 10, by state and territory (ABS 2006, 2011, 2016).

Figure 2. Apparent retention rates (2000-2015) for Year 10 to 12, by state and territory (ABS 2006, 2011, 2016).

Figure 3. Bronfenbrenner's model of ecology

(http://intascprinciple2.weebly.com/uploads/7/1/0/3/7103825/902452.jpg?385) 